\title{
Penerapan Pijat Bayi Terhadap Peningkatan Berat Badan Bayi Usia 1-3 Bulan : Literature Review
}

\author{
Runi Karin Majid ${ }^{1 *}$, Aida Rusmariana² \\ ${ }^{1,2}$ Program Studi Diploma Tiga Keperawatan, Universitas Muhammadiyah Pekajangan \\ Pekalongan, Indonesia \\ *email : runikarin07@gmail.com
}

\begin{abstract}
Baby massage is one of the oldest and most popular types of stimulation or touch therapy that is has been practiced for a long time almost all over the world, including in Indonesia for generations. Baby massage has many benefits if done regularly, one of which can increase body weight. The purpose of this study was to know the weight of babies aged 1-3 months before and after being given baby massage. The method was a literature review of three research articles from Google Sholar used keywords including baby massage, weight gain, infants aged 1-3 months and articles published in the last 10 years. The results of the literarture review of three articles in the experimental group, before being given baby massage, was the median value of 4,592 grams and the minimum-maximum value of 3,533-5,933 grams. The control group had a median value of 4,258 grams and a minimum-maximum value of 3,533-5,200 grams. The experimental group after being given baby massage had a median value of 5,717 grams and a minimum-maximum value of 4,433-6,900 grams. While the control group had a median value of 4,767 grams and a minimummaximum value of 3,967-5,633 grams. The conclusion of the literature review from these three articles is that baby massage has an effect on increasing body weight in infants aged 1-3 months. The results of the three articles that had been reviewed are babies who get massage therapy had a higher weight gain compared to babies who do not get massage therapy. It is suggested for nurses to be able to apply and provide education to parents to do baby massage in order to overcome the problem of baby growth and development especially the problem of baby massage.
\end{abstract}

Keywords: Infants aged 1-3 months, Baby massage, Eigh gain

\begin{abstract}
Abstrak
Pijat bayi merupakan salah satu jenis stimulasi atau terapi sentuhan tertua dan terpopuler yang sudah lama dilakukan hampir di seluruh dunia termasuk di Indonesia secara turun temurun. Pijat bayi yang dilakukan secara rutin akan memberikan banyak manfaat yaitu salah satunya dapat meningkatkan berat badan. Tujuan dari penulisan ini yaitu untuk mengetahui berat badan bayi usia 1-3 bulan sebelum dan sesudah diberikan pijat bayi. Metode penulisan menggunakan literature review dari tiga artikel penelitian yang didapatkan dari google scholar dengan kata kunci pijat bayi, peningkatan berat badan dan bayi usia 1-3 bulan dan minimal terbit 10 tahun terakhir. Hasil dari literature review ketiga artikel ilmiah sebelum diberikan pijat bayi pada kelompok eksperimen memiliki nilai median 4.592 gram dan nilai minimum-maksimum 3.533-5.933 gram. Pada kelompok kontrol memiliki nilai median 4.258 gram dan nilai minimum-maksimum 3.533-5.200 gram. Sesudah diberikan pijat bayi pada kelompok eksperimen memiliki nilai median 5.717 gram dan nilai minimum-maksimum 4.433-6.900 gram. Sedangkan pada kelompok kontrol memiliki nilai median 4.767 gram dan nilai minimum-maksimum 3.967-5.633 gram. Simpulan literatur review dari ketiga artikel ilmiah yaitu pijat bayi sama-sama memiliki pengaruh untuk meningkatkan berat badan pada bayi usia 1-3 bulan. Hasil dari ketiga artikel ilmiah yang telah dilakukan literature review menunjukkan bahwa bayi yang mendapatkan pijat mengalami peningkatan berat badan lebih tinggi dibandingkan dengan bayi yang tidak mendapatkan terapi pijat. Saran bagi perawat untuk dapat menerapkan dan memberikan edukasi kepada orang tua untuk melakukan pijat bayi guna mengatasi masalah tumbuh kembang pada bayi terutama masalah berat badan bayi.
\end{abstract}

Kata kunci: Bayi Usia 1-3 Bulan; Pijat bayi; Peningkatan Berat Badan 


\section{Prosiding Seminar Nasional Kesehatan 2021 Lembaga Penelitian dan Pengabdian Masyarakat Universitas Muhammadiyah Pekajangan Pekalongan}

\section{Pendahuluan}

Pijat bayi merupakan salah satu jenis stimulasi atau terapi sentuhan tertua dan terpopuler yang sudah lama dilakukan hampir di seluruh dunia termasuk di Indonesia secara turun temurun. Pijat bayi yang dilakukan secara rutin akan memberikan manfaat diantaranya yaitu peningkatan berat badan, membantu sirkulasi dan perkembangan saraf, membantu mengatasi masalah tidur, nafsu makan bertambah, merangsang sistem sensorik, menstimulasi pertumbuhan hormon, memberikan rasa rileks dan mempererat hubungan bayi dengan orang tua (Astuti, Susanti \& Permatasari, 2017). Pijat dapat meningkatkan berat badan bayi karena pijat yang diberikan akan merangsang saraf nervus vagus. Rangsangan dari saraf nervus vagus akan merangsang pengeluaran hormon gastrin dan insulin yang akan menyebabkan terjadinya penyerapan sari makanan menjadi lebih baik. Penyerapan sari makanan menjadi lebih baik akan menyebabkan peningkatan yang pesat terhadap berat badan bayi (Fitriyanti, Arsyad \& Sumiaty, 2019).

Pijat bayi yang diberikan 15 menit sebanyak 2 kali dalam seminggu selama 6 minggu pada bayi usia 1-3 bulan akan meningkatkan berat badan secara terkontrol (Proverawati \& Sulistyorini, 2014). Hasil penelitian dari dari Agustin, Arum, dan Noviadi (2020) membuktikan bahwa pijat bayi berpengaruh terhadap peningkatan berat badan bayi usia 1-3 bulan yang dilakukan selama 6 kali dalam 3 minggu dan didapatkan peningkatkan berat badan bayi yang dilakukan terapi pijat. Hasil dari penelitian tersebut sesuai dengan penelitian Irva, Hasanah, dan Woferst (2014) yang menunjukkan bahwa terdapat pengaruh pijat bayi terhadap peningkatan berat badan bayi usia 1-3 bulan dan didapatkan peningkatan berat badan bayi yang diberikan terapi pijat pada pagi dan sore selama 2 minggu pemijatan. Penelitian Astuti, Susanti dan Permatasari (2017) juga menghasilkan adanya peningkatan berat badan bayi usia 1-3 bulan setelah diberikan terapi pijat.

Berdasarkan Survei Demografi dan Kesehatan Indonesia (SDKI) pada tahun 2017 menyatakan bahwa jumlah bayi di Indonesia mencapai 14.261.868 jiwa yang diantaranya bayi mengalami berat badan di Bawah Garis Merah dengan presentase 3,5\%. Data dari Dinas Provinsi Kesehatan Sulawesi Tengah menunjukkan bahwa jumlah bayi pada tahun 2017 ada sebanyak 60.715 jiwa dengan presentase 4,7\% bayi mengalami berat badan di Bawah Garis Merah (BGM) dan data dari Dinas Kesehatan Kota Palu tahun 2017 menunjukkan jumlah bayi ada sebanyak 7802 jiwa dengan presentase 2,1\% bayi mengalami berat badan di Bawah Garis Merah (BGM) (Fitriyanti, Arsyad \& Sumiaty, 2019).

Pada tahun 2016, ada sebanyak 55.829 bayi dan balita ditimbang di Kabupaten Pekalongan yang diantaranya ada 525 jiwa megalami berat badan di Bawah Garis Merah (BGM). Data pada bulan Desember tahun 2017 ada sebanyak 55.948 bayi dan balita ditimbang dan ada 318 jiwa yang mengalami berat badan di Bawah Garis Merah (BGM) (Hidayah, Aulia \& Nugraheni, 2020). Berdasarkan studi pendahuluan yang dilakukan di Dinas Kesehatan Semarang pada tahun 2017 terdapat sebanyak 16,34\% bayi dan balita di Puskesmas Halmahera yang mengalami berat badan di Bawah Garis Merah (BGM). Kondisi berat badan di Bawah Garis Merah (BGM) akan menjadi suatu bentuk permasalahan kekurangan asupan gizi yang diperlukan oleh tubuh. Ketika 


\section{Prosiding Seminar Nasional Kesehatan Lembaga Penelitian dan Pengabdian Masyarakat Universitas Muhammadiyah Pekajangan Pekalongan}

tubuh mengalami kekurangan gizi dalam waktu yang lama dapat menimbulkan dampak pada fungsi perkembangan otak yang menurun (rata-rata akan terjadi pada usia 2-3 tahun), fungsi perkembangan kognitif menurun, sistem pembentukan saraf terganggu dan metabolisme tubuh akan mengalami gangguan (Putri, BM \& Shaluhiyah, 2020).

Dari uraian di atas terdapat beberapa penelitian yang menyebutkan bahwa pijat bayi dapat berpengaruh terhadap peningkatan berat badan bayi, serta data bayi yang mengalami gangguan pertumbuhan. Sebagaimana diketahui bahwa pijat bayi merupakan salah satu jenis stimulasi atau terapi sentuhan yang dapat meningkatkan berat badan sehingga mampu mengatasi gangguan pertumbuhan pada bayi. Oleh karena itu, penulis tertarik untuk melakukan literature review dengan judul "Penerapan Pijat Bayi Terhadap Peningkatan Berat Badan Bayi Usia 1-3 Bulan."

\section{Literature Review}

Pemberian stimulasi akan meningkatkan pertumbuhan dan perkembangan pada bayi. Stimulasi yang rutin diberikan pada bayi juga akan merangsang perkembangan sel-sel otak dan memperkuat hubungan antar syaraf yang telah terbentuk sehingga secara otomatis fungsi otak bayi akan menjadi semakin baik sehingga dapat meminimalisir terjadinya gangguan pertumbuhan pada bayi terutama bayi usia 1-3 bulan yang belum mendapatkan makanan pendamping ASI. Stimulasi yang dianjurkan salah satunya ialah pijat bayi (Agustin, Arum \& Noviadi, 2020).

Pijat bayi merupakan suatu jenis stimulasi atau terapi sentuhan yang diberikan pada bayi dalam bentuk sentuhan yang ringan sampai sedang. Pijat bayi juga dijelaskan sebagai seni perawatan kesehatan dan pengobatan yang telah lama dikenal oleh masyarakat di Indonesia bahkan di seluruh dunia dan sudah dipraktekkan secara turun temurun (Rahmania, 2015). Salah satu manfaat dari pijat bayi yaitu dapat meningkatkan berat badan. Peningkatan berat badan pada bayi adalah salah satu tanda kesehatan bayi sehingga hal tersebut dijadikan sebagai tolak ukur pertumbuhan bayi. Bayi usia 1-3 bulan akan mengalami masa pertumbuhan paling cepat sehingga disarankan untuk menjaga berat badan sesuai dengan usia (Fitriyanti, Arsyad \& Sumiaty, 2019).

Nurhasanah, Nugraha dan Ariswati (2013) menyebutkan bahwa alat ukur yang digunakan untuk menimbang berat badan bayi usia 0-12 bulan ialah timbangan bayi. Timbangan bayi diletakkan di atas meja yang datar dan tidak mudah goyah. Sebelum melakukan penimbangan, hal yang pertama dilakukan yaitu melihat posisi jarum (jarum menunjukkan angka 0). Biasanya bayi ditimbang dengan posisi terbaring terlentang atau duduk tanpa baju. Setelah itu hasil dari penimbangan berat badan akan dapat diketahui dengan cara membaca angka yang ditunjukkan oleh jarum timbangan tersebut (Muazar, 2015 diambil dari Nurhasanah, et al., 2013).

\section{Metode}

Metode yang digunakan dalam artikel ini yaitu literature review. Subyek dalam artikel ini adalah hasil penelitian yang sudah dipublikasikan sejumlah 3 artikel penelitian dengan subyek penelitian bayi usia 1-3 bulan. Kriteria inklusi dalam artikel ini ialah bayi yang berusia 1-3 bulan yang diperbolehkan ibu nya untuk diberikan terapi pijat. Kriteria eksklusi adalah bayi yang berusia kurang dari 1 bulan atau lebih dari 3 


\section{Prosiding Seminar Nasional Kesehatan $\mathbf{2 0 2 1}$ Lembaga Penelitian dan Pengabdian Masyarakat Universitas Muhammadiyah Pekajangan Pekalongan}

bulan dan bayi yang usia 1-3 bulan yang tidak diperbolehkan diberikan terapi pijat. Metode pengumpulan data dalam artikel ini dilakukan dengan mencari artikel ilmiah yang telah dipublikasikan tentang "Pengaruh Pijat Bayi Terhadap Peningkatan Berat Badan Bayi Usia 1-3 Bulan" di laman web google scholar dengan menggunakan kata kunci pijat bayi, peningkatan berat badan, bayi usia 1-3 bulan dan minimal terbit 10 tahun terakhir kemudian diseleksi dan dipaparkan struktur penulisan artikel ilmiah tersebut dan dilakukan analisis. Dari hasil analisis menunjukkan bahwa terdapat 3 artikel ilmiah yang sesuai dengan topik. Ketiga artikel ilmiah tersebut memiliki metode penelitian yang hampir sama, alat ukur berat badan bayi sama-sama menggunakan timbangan bayi, satuan berat badan bayi menggunakan gram dan data dari hasil artikel ilmiah berupa numerik yaitu nilai median, nilai minimum-maksimum.

\section{Hasil dan Pembahasan}

\section{Hasil}

Dari 3 artikel ilmiah yang dilakukan literature review hanya 2 artikel ilmiah yang menampilkan karakteristik responden berdasarkan umur dan jenis kelamin. Kedua artikel ilmiah tersebut yaitu artikel dari penulis Tri Sasmi Irva, Oswati Hasanah dan Rismadefi Woferst (2014), dan artikel dari Ismar Agustin, Khenia Arini Sekar Arum, dan Pitri Noviadi (2020). Karakteristik dari 2 artikel tersebut dengan total 64 responden dijelaskan dalam tabel 4.1 dan 4.2.

Tabel 4.1 Distribusi Frekuensi Karakteristik Responden Berdasarkan Umur (N : 64)

\begin{tabular}{ccccccccc}
\hline $\begin{array}{c}\text { Umur } \\
\text { (Bulan) }\end{array}$ & \multicolumn{2}{c}{$\begin{array}{c}\text { Artikel 1 } \\
(\mathrm{N}: 34)\end{array}$} & \multicolumn{2}{c}{$\begin{array}{c}\text { Artikel 2 } \\
(\mathrm{N}: 30)\end{array}$} & \multicolumn{2}{c}{$\begin{array}{c}\text { Artikel 3 } \\
(\mathrm{N}: 12)\end{array}$} & \multicolumn{2}{c}{ Total } \\
\cline { 2 - 10 } & $\mathrm{f}$ & $\%$ & $\mathrm{f}$ & $\%$ & $\mathrm{f}$ & $\%$ & $\mathrm{f}$ & $\%$ \\
\hline 1 & 16 & 47 & 8 & 26,7 & - & - & 24 & 37,5 \\
2 & 11 & 32,4 & 8 & 26,7 & - & - & 19 & 29,7 \\
3 & 7 & 20,6 & 14 & 46,6 & - & - & 21 & 32,8 \\
\hline
\end{tabular}

Berdasarkan tabel di atas diketahui bahwa sebagian besar responden berumur 1 bulan $(37,5 \%)$ dengan jumlah responden 24 bayi.

Tabel 4.2.Distribusi Frekuensi Karakteristik Responden Berdasarkan Jenis Kelamin $(\mathrm{N}: 76)$

\begin{tabular}{ccccccccc}
\hline Jenis Kelamin & \multicolumn{2}{c}{$\begin{array}{c}\text { Artikel 1 } \\
(\mathrm{N}: 34)\end{array}$} & \multicolumn{2}{c}{$\begin{array}{c}\text { Artikel 2 } \\
(\mathrm{N}: 30)\end{array}$} & \multicolumn{2}{c}{$\begin{array}{c}\text { Artikel 3 } \\
(\mathrm{N}: 12)\end{array}$} & \multicolumn{2}{c}{ Total } \\
& $\mathrm{f}$ & $\%$ & $\mathrm{f}$ & $\%$ & $\mathrm{f}$ & $\%$ & $\mathrm{f}$ & $\%$ \\
\hline \multirow{2}{*}{ Laki-laki } & 19 & 55.9 & 15 & 50 & - & - & 34 & 53,1 \\
Perempuan & 15 & 44,1 & 15 & 50 & - & - & 30 & 46,9 \\
\hline
\end{tabular}

Dari tabel di atas dapat diketahui bahwa jumlah responden laki-laki lebih banyak dibandingkan dengan responden perempuan yaitu 34 responden $(53,1 \%)$. 


\section{Prosiding Seminar Nasional Kesehatan Lembaga Penelitian dan Pengabdian Masyarakat Universitas Muhammadiyah Pekajangan Pekalongan

Tabel 4.3 Distribusi Nilai Median dan Nilai Minimum-Maksimum Berat Badan Responden Sebelum Diberikan Pijat Bayi (N : 76)

\begin{tabular}{ccccc}
\hline \multirow{2}{*}{ Artikel Ilmiah } & \multicolumn{2}{c}{ Kelompok Eksperimen $(\mathrm{N}: 38)$} & \multicolumn{2}{c}{ Kelompok Kontrol (N : 38) } \\
\cline { 2 - 5 } & Median (gram) & $\begin{array}{c}\text { Min-maks } \\
(\mathrm{gram})\end{array}$ & $\begin{array}{c}\text { Median }(\mathrm{gram}) \\
(\mathrm{gram})\end{array}$ \\
\hline $1(\mathrm{~N}: 34)$ & 4.900 & $3.400-5.800$ & 4.000 & $3.400-5.000$ \\
$2(\mathrm{~N}: 30)$ & 4.700 & $3.200-7.000$ & 4.600 & $3.200-5.600$ \\
$3(\mathrm{~N}: 12)$ & 4.175 & $4.000-5.000$ & 4.175 & $4.000-5.000$ \\
\hline Total $(\mathrm{N}: 76)$ & 4.592 & $3.533-5.933$ & 4.258 & $3.533-5.200$ \\
\hline
\end{tabular}

Tabel 4.4 Distribusi Nilai Median dan Nilai Minimum-Maksimum Berat Badan Responden Sesudah Diberikan Pijat Bayi (N : 76)

\begin{tabular}{ccccc}
\hline Artikel Ilmiah & \multicolumn{2}{c}{ Kelompok Eksperimen $(\mathrm{N}: 38)$} & \multicolumn{2}{c}{ Kelompok Kontrol (N : 38) } \\
\cline { 2 - 5 } & Median (gram) & $\begin{array}{c}\text { Min-maks } \\
(\mathrm{gram})\end{array}$ & Median (gram) & $\begin{array}{c}\text { Min-maks } \\
(\mathrm{gram})\end{array}$ \\
\hline $1(\mathrm{~N}: 34)$ & 5.600 & $4.200-6.400$ & 4.500 & $3.900-5.500$ \\
$2(\mathrm{~N}: 30)$ & 6.000 & $4.000-8.100$ & 4.900 & $3.600-6.000$ \\
$3(\mathrm{~N}: 12)$ & 5.550 & $5.100-6.200$ & 4.900 & $4.400-5.400$ \\
\hline Total $(\mathrm{N}: 76)$ & 5.175 & $4.433-6.900$ & 4.767 & $3.967-5.633$ \\
\hline
\end{tabular}

Berdasarkan tabel 4.3.dan 4.4 diketahui bahwa pada kelompok yang diberikan pijat bayi (kelompok eksperimen) mengalami peningkatan berat badan yang lebih banyak dibanding dengan kelompok yang tidak diberikan pijat bayi (kelompok kontrol). Peningkatan berat badan bayi pada kelompok eksperimen setelah diberikan pijat bayi mencapai 583 gram sedangkan pada kelompok kontrol peningkatan berat badan bayi sebesar 509 gram.

\section{Pembahasan}

Berdasarkan ketiga artikel ilmiah yang telah dilakukan literature review, bayi yang diberikan intervensi pijat yaitu usia 1-3 bulan dikarenakan bayi pada usia beberapa bulan pertama dalam kehidupan (1-6 bulan) akan membutuhkan makanan yang memiliki gizi tinggi agar dapat mencapai pertumbuhan dan perkembangan yang optimal (Irva, Hasanah \& Woferst, 2014). Pada artikel penelitian ke 1 dan 2 menggunakan karakteristik jenis kelamin yaitu laki-laki dan perempuan. Hasil dari artikel penelitian ke 1 didapatkan responden laki-laki lebih banyak daripada responden perempuan. Irva, Hasanah dan Woferst (2014), proses pertumbuhan pada laki-laki lebih besar jika dibandingkan dengan perempuan. Berat badan bayi perempuan yang lahir dengan cukup bulan akan lebih ringan sekitar 14 gram dibandingkan dengan bayi laki-laki yang lahir cukup bulan. Proses tumbuh kembang pada laki-laki juga cenderung lebih baik daripada perempuan karena pengaruh perilaku ibu dan keluarga dalam mengasuh anak contohnya seperti memberikan prioritas makanan yang bergizi dan menjaga kesehatan nya.

Ketiga artikel penelitian yang telah dilakukan literature review menunjukkan bahwa pijat bayi dapat meningkatkan berat badan bayi usia 1-3 bulan. Hal itu dikarenakan pijat yang diberikan pada bayi dapat merangsang saraf nervus vagus dan juga merangsang pengeluaran hormon pencernaan seperti gastrin dan insulin. 


\section{Prosiding Seminar Nasional Kesehatan 2021 Lembaga Penelitian dan Pengabdian Masyarakat Universitas Muhammadiyah Pekajangan Pekalongan}

Peningkatan hormon gastrin dan insulin akan merangsang fungsi pencernaan yang dapat mempercepat pengosongan lambung. Pengosongan lambung yang lebih cepat akan membuat bayi mudah lapar sehingga frekuensi menyusu meningkat atau dapat diartikan sebagai penyerapan makanan menjadi lebih baik sehingga dengan mudah berat badan akan meningkat (Carolin, Suprihatin \& Agustin, 2020).

Hasil dari literature review ketiga artikel ilmiah sebelum diberikan pijat bayi pada kelompok eksperimen memiliki nilai median 4.592 gram dan nilai minimum-maksimum 3.533-5.933 gram. Pada kelompok kontrol memiliki nilai median 4.258 gram dan nilai minimum-maksimum 3.533-5.200 gram. Sesudah diberikan pijat bayi pada kelompok eksperimen memiliki nilai median 5.717 gram dan nilai minimum-maksimum 4.4336.900 gram sedangka pada kelompok kontrol memiliki nilai median 4.767 gram dan nilai minimum-maksimum 3.967-5.633 gram.

\section{Kesimpulan}

Berdasarkan ketiga artikel ilmiah yang telah dilakukan literature review dapat disimpulkan bahwa pijat bayi memiliki pengaruh dalam meningkatkan berat badan pada bayi usia 1-3 bulan. Hasil dari ketiga artikel ilmiah yang telah dilakukan literature review menunjukkan bahwa bayi yang mendapatkan pijat mengalami peningkatan berat badan lebih tinggi dibandingkan dengan bayi yang tidak mendapatkan terapi pijat. Saran bagi institusi pelayanan kesehatan yaitu diharapkan pijat bayi dapat dijadikan sebagai terapi dalam mengatasi masalah tumbuh kembang pada bayi di Pelayanan Kesehatan.

\section{Ucapan Terima Kasih}

Dalam hal ini penulis mengucapkan terima kasih kepada ibu Aida Rusmariana selaku pembimbing yang telah memberikan dukungan moril maupun materiil dalam penyelesaian publikasi ini.

\section{Referensi}

[1] Agustin, I. Arum, K., A., S. Noviadi, P. Pengaruh Pijat Bayi Terhadap Peningkatan Berat Badan Bayi Usia 1-3 Bulan. Jurnal 'Aisyiyah Medika, 5(2), 166-167. doi:10.1136729, 2020.

[2] Astuti, W., T. Susanti, E., T. Permatasari, M. Pijat Bayi Terhadap Berat Badan Bayi Usia 1-3 Bulan. Jurnal Keperawatan, 3(1), 1-7, 2017.

[3] Carolin, B., T. Suprihatin. Agustin, C. Pijat Bayi Dapat Menstimulus Peningkatan Berat Badan Bayi. Jurnal IImiah Kebidanan Indonesia, 10 (2), 2020.

[4] Fitriyanti, F., E. Arsyad, G. Sumiaty. Pengaruh Pijat Bayi Terhadap Peningkatan Berat Badan.Jurnal Bidan Cerdas. 1(3), 2019.

[5] Hidayah, N. Aulia, D. Nugraheni, I. Efektivitas Pemberian Es Krim Modisco Kacang Merah dan Es Krim Modisco Daun Kelor Terhadap Peningkatan Berat Badan Balita Bawah Garis Merah (BGM) Di Wilayah Kerja Puskesmas Karanganyar Kabupaten Pekalongan. Journal Of Applied Health Management And Technology.2(2), 2020.

[6] Irva, T., S. Hasanah, O. Woferst, R. Pengaruh Terapi Pijat Terhadap Peningkatan Berat Badan Bayi. Jurnal Online Mahasiswa Program Studi IImu Keperawatan Universitas Riau, 1(2), 2014. 


\section{Prosiding Seminar Nasional Kesehatan 2021 Lembaga Penelitian dan Pengabdian Masyarakat Universitas Muhammadiyah Pekajangan Pekalongan}

[7] Muazar, H. Analisis Kebutuhan Anak Usia Dini (Buku Ajar S1 PAUD). dalam Nurhasanah, R., Nugraha, P., C., \& Ariswati, H., G. (2017). Alat Pengukur Berat Badan, Panjang Badan dan Lingkar Kepala Bayi Dengan Tampilan Grafik (Berat Badan Bayi). Digital Library Politeknik Kesehatan Kemenkes Surabaya, 2015.

[8] Nurhasanah, R., Nugraha, P., C., \& Ariswati, H., G. Alat Pengukur Berat Badan, Panjang Badan dan Lingkar Kepala Bayi Dengan Tampilan Grafik (Berat Badan Bayi). Digital Library Politeknik Kesehatan Kemenkes Surabaya, 2017.

[9] Proverawati, A. Sulistyorini, C., I. Berat Badan Lahir Rendah (BBLR). Yogyakarta : Nuha Medika, 2014.

[10] Putri, C., D., P. BM, S. Shaluhiyah, Z. Faktor Risiko Pada Balita Dengan Berat Badan Di Bawah Garis Merah (BGM) Di Wilayah Kerja Puskesmas Halmahera. Jurnal Kesehatan Masyarakat. 8(4), 2020. 